\section{IMPLIKASI YURIDIS PASAL 46 UU NO 44 THN 2009 TENTANG RUMAH SAKIT TERHADAP KELALAIAN YANG DILAKUKAN TENAGA KESEHATAN DALAM HAL INI TENAGA MEDIS ${ }^{1}$ Oleh: Billy Imanuel Mingkid ${ }^{2}$}

\begin{abstract}
ABSTRAK
Tujuan dilakukannya penelitian yaitu untuk mengetahui apakah rumah sakit sepenuhnya bertanggung jawab atas kelalaian yang dilakukan tenaga kesehatan dan dalam hal apa tenaga medis selaku staf di rumah sakit bertanggung jawab atas kelalaian yang dilakukannya, yang dengan metpde penelitian hukum normatif disimpulkan: Hubungan

antara rumah sakit-dokter-pasien adalah berdasarkan hubungan terapeutik yang dimana melahirkan hak dan kewajiban dari para pihak. Pada pasal 46 Undang-Undang Nomor 44 Tahun 2009 tentang Rumah Sakit dapat ditafsirkan bahwa rumah sakit dapat bertanggungjawab terhadap kelalaian tenaga kesehatan, Rumah Sakit dapat bertanggung jawab terhadap kerugian akibat dari kelalaian, Rumah Sakit tidak bertanggung jawab jika terbukti tidak adanya kelalaian yang dilakukan tenaga kesehatan, Rumah Sakit tidak bertanggung jawab terhadap tindakan kesengajaan tenaga kesehatan yang menimbulkan kerugian seseorang, Rumah Sakit tidak bertanggung jawab terhadap kelalaian akibat tindakan medis yang dilakukan tenaga medis yang bukan pegawainya, Tenaga Medis dapat bertanggung jawab terhadap kerugian yang ditimbulkan akibat dari kelalaian yang dilakukannya.

Kata kunci: rumah sakit; tenaga kesehatan;
\end{abstract}

\section{PENDAHULUAN}

\section{A. Latar Belakang}

Malpraktik yang dilakukan oleh tenaga kesehatan dapat berupa malpraktik medik dan malpraktik di bidang medik. Malpraktik di bidang medik yaitu malpraktik yang dilakukan tenaga kesehatan ketika ia menjalankan profesinya di bidang medik. Dalam hal ini dapat berupa perbuatan yang disengaja (intentional) seperti pada misconduct tertentu, tindakan

\footnotetext{
${ }^{1}$ Artikel Skripsi. Dosen Pembimbing: Josina E. Londa, SH., MH; Dr. Theodorus H.W. Lumenon, SH., MHum

2 Mahasiswa pada Fakultas Hukum Unsrat, NIM. 16071101153
}

kelalaian (negligence), ataupun suatu kekurang mahiran/ketidak kompetenan yang tidak beralasan (unreasonable lack of skill), yang mengakibatkan luka, atau menderita kerugian pada pihak yang ditangani. World Medical Association mengingatkan tidak semua kegagalan medik adalah malpraktik medik. Jika terjadi peristiwa buruk tidak dapat diduga sebelumnya (unforeseeable) pada saat dilakukan tindakan medis yang sesuai standar tetapi mengakibatkan cedera pada pasien, maka hal ini tidak termasuk dalam pengertian malpraktik. ${ }^{3}$ Dalam pasal 46 Undang-Undang No 44 Tahun 2009 tentang Rumah Sakit menyebutkan bahwa Rumah Sakit bertanggungjawab atas semua kelalaian yang dilakukan oleh tenaga kesehatan yang dalam hal ini termasuk tenaga medis yang dimana banyak menimbulkan pertanyaan bahkan kritikan dalam pasal ini, dikarenakan adanya ketidakadilan kepada Rumah Sakit yang di tuntut karena kelalaian tenaga kesehatan yang di dalamnya termasuk Tenaga Medis. Padahal kita tahu bersama Tenaga Medis mempunyai tanggung jawab profesinya yang di atur dalam Kode Etik Kedokteran Indonesia (Kodeki) keseluruhannya ada 21 pasal yang mengatur mengenai tanggung jawab atau kewajiban dokter dalam bekerja sebagai tenaga medis. ${ }^{4}$ Dalam hal mengenai tenaga kesehatan seperti yang di jelaskan dalam Undang-Undang Nomor 36 Tahun 2009 Tentang kesehatan yaitu Tenaga Kesehatan adalah setiap orang yang mengabdikan diri dalam bidang kesehatan serta memiliki pengetahuan dan atau ketrampilan melalui pendidikan di bidang kesehatan yang untuk jenis tertentu memerlukan kewenangan untuk melakukan upaya kesehatan.

\section{B. Rumusan Masalah}

1. Apakah rumah sakit sepenuhnya bertanggung jawab atas kelalaian yang dilakukan tenaga kesehatan?

2. Dalam hal apa tenaga medis selaku staf di rumah sakit bertanggung jawab atas kelalaian yang dilakukannya?

\footnotetext{
${ }^{3}$ Fh.unsoed.ac.id - Tanggung jawab rumah sakit terhadap kerugian akibat kelalaian tenaga kesehatan dan implikasinya., diakes tanggal 5 oktober 2019

${ }^{4}$ www.mkekpbidi.org - Kodeki | MKEK PB IDI diakses tanggal 14 oktober 2019
} 


\section{Metode Penelitian}

Dalam penelitian ini penulis menggunakan pendekatan yuridis normative.

\section{PEMBAHASAN}

\section{A. Tanggung Jawab Rumah Sakit Atas Kelalaian Tenaga Medis}

Penyelenggaraan manajemen kesehatan dirumah sakit, terdapat pengelolaan yang berkaitan dengan tiga hal yang merupakan tanggung jawab rumah sakit secara umum. Tiga hal tersebut yaitu: pengelolaan rumah sakit yang berkaitan dengan personalia; pengelolaan rumah sakit yang berkaitan dengan pelaksanaan tugas; dan pengelolaan yang berkaitan dengan duty of care. ${ }^{5}$ Oleh karena itu, penyelenggaraan kegiatan rumah sakit, terdapat kegiatan-kegiatan yang menimbulkan tanggung jawab pengelolaan atau manajemen rumah sakit dan tanggung jawab para tenaga professional kesehatan dirumah sakit, ${ }^{6}$ yang terdiri: tanggung jawab pengelola rumah sakit; dan tanggung jawab kesehatan (dokter, perawat).

Berdasarkan UU Rumah Sakit, rumah sakit bertanggung jawab terhadap semua kerugian yang menimpa seseorang sebagai akibat dari kelalaian tenaga kesehatan di rumah sakit, sebagaimana ditentukan pada pasal 46 Undang-Undang Nomor 44 tahun 2009. Ketentuan pasal 46 ini menjadi dasar yuridis bagi seseorang untuk meminta tanggung jawab pihak rumah sakit jika terjadi kelalaian tenaga kesehatan yang menimbulkan kerugian. Berdasarkan rumusan pasal 46 tersebut, dapat ditafsirkan beberapa hal. Pertama, rumah sakit bertanggung jawab terhadap kerugian, sebatas akibat dari kelalaian tenaga kesehatan di rumah sakit; kedua, rumah sakit tidak bertanggung jawab semua kerugian seseorang, jika ternyata terbukti tidak ada tindakan kelalaian dari tenaga kesehatan di rumah sakit; ketiga, rumah sakit tidak bertanggung jawab terhadap tindakan kesengajaan tenaga kesehatan yang menimbulkan kerugian seseorang bukan menjadi tanggung jawab rumah sakit; dan keempat, rumah sakit bertanggung jawab

\footnotetext{
5 Husein Kerlaba, Segi-Segi Etis dan Yuridis Informed Concent, Jakarta: Pustaka Sinar Harapan, 1993, hIm 97

6 Nusye KI Jayanti, Penyelesaian Hukum dalam Malapraktik Kedokteran, Yogyakarta: Pustaka Yustisia, hlm 24
}

terhadap tindakan kelalaian tenaga kesehatan, jika kelalaian tersebut dilakukan dan terjadi dirumah sakit.

Lebih lanjut untuk menentukan sejauh mana tanggung jawab rumah sakit terhadap tindakan kelalaian tenaga kesehatan dirumah sakit, secara teoritik dilihat dari pelbagai aspek, seperti: pola hubungan terapeutik; pola hubungan kerja tenaga kesehatan dirumah sakit; Rumah sakit sebagai korporasi; dan jenis malpraktik yang dilakukan oleh tenaga kesehatan. Satu persatu akan diuraian tentang aspek-aspek yang menjadi dasar pemikiran rumah sakit bertanggung jawab atas kelalaian tenaga kesehatan dirumah sakit.

Dasar pembenaran/relevansi rumah sakit bertanggung jawab atas kelalaian tenaga kesehatan dalam (khususnya dokter), dapat pula dilihat dari aspek kondisi hubungan terapeutik (hubungan kepentingan medis) antara pasien dan rumah sakit. Pola hubungan terapeutik di rumah sakit, dapat dalam bentuk hubungan pasien dan rumah sakit; pola hubungan pasien dan dokter; jika pola hubungan terapeutik antara pasien dan rumah sakit, maka kedudukan rumah sakit sebagai pihak yang memberikan prestasi, sementara dokter hanya berfungsi sebagai employee (subordinate dari rumah sakit) yang bertugas melaksanakan kewajiban rumah sakit. Dalam bahasa lain, kedudukan rumah sakit adalah sebagai principal dan dokter sebagai agent. Sedangkan pasien berkedudukan adalah sebagai pihak yang wajib memberi kontraprestasi. Hubungan seperti ini biasanya berlaku bagi rumah sakit milik pemerintah yang dokter-dokternya digaji secara tetap dan penuh, tidak didasarkan atas jumlah pasien yang telah ditangani ataupun kualitas serta kuantitas tindakan medik yang dilakukan dokter. Dengan adanya pola hubungan terapeutik ini (hubungan pasien-rumah sakit), maka jika terdapat kerugian yang diderita oleh pasien karena kelalaian dokter (tenaga kesehatan), maka dalam hal ini rumah sakit dapat bertanggung jawab.

Pola hubungan pasien-dokter terjadi jika pasien sudah dalam keadaan berkompeten dan dirawat dirumah sakit yang dokter-dokternya bekerja bukan sebagai employee, tetapi sebagai mitra (attending physician). Pola seperti ini menempatkan dokter dan rumah sakit dalam 
kedudukan yang sama derajat. Dokter sebagai pihak yang wajib memberikan prestasi, sedangkan fungsi rumah sakit hanyalah sebagai tempat yang menyediakan fasilitas (tempat tidur, makan minum, perawat/bidan serta sarana medik dan non medik). Konsepnya seolah-olah rumah sakit menyewakan fasilitasnya kepada dokter yang memerlukannya. Pola seperti in banyak dianut oleh rumah sakit swasta dimana dokternya menempatkan penghasilan berdasarkan jumlah pasien, kwantitas dan kealitas tindakan medik yang dilakukan. Jika dalam satu bulan tidak ada pasien pun yang dirawat maka bulan itu dokter tidak menghasilkan apa-apa. Dengan pola hubungan pasien-dokter, jika ada kelalaian (tenaga kesehatan) yang menyebabkan kerugian pada pasien, maka dokter (tenaga kesehatan) yang bertanggung jawab, dan bukan menjadi tanggung jawab rumah sakit.

Ada beberapa macam pola yang berkembang dalam kaitannya dengan hubungan kerja antara tenaga kesehatan (dokter) dan rumah sakit antara lain: dokter sebagai tenaga kerja (employee); dokter sebagai mitra (attending physician); dokter sebagai independent contractor. ${ }^{7}$ Masingmasing dari pola hubungan kerja tersebut akan sangat menentukan apakah rumah sakit harus bertanggung jawab atau tidak terhadap kerugian yang disebabkan oleh kesalahan dokter serta sejauh mana tanggung jawab/gugat yang harus dipikul. Mengenai dokter sebagai employee dan dokter sebagai attending physician sudah cukup disinggung di bagian depan. Seperti telah disinggung diatas tentang pola hubungan terapeutik, jika hubungan kerja dokter sebagai employee, maka jika terjadi kerugian pada pasien karena tindakan dokter, pihak rumah sakit yang bertanggung jawab. Demikian pula jika dokter sebagai attending physician, jika ada kelalaian dokter (tenaga kesehatan) yang menyebabkan kerugian pada pasien, maka dokter (tenaga kesehatan) yang bertanggung jawab, dan bukan menjadi tanggung jawab rumah sakit.

Untuk menjelaskan tentang dokter sebagai independent contractor, diberikan ilustrasi sebagai berikut. Didalam suatu kegiatan operasi merupakan tindakan medik yang memerlukan

${ }^{7}$ Sofwan Dahlan, Hukum Kesehatan: Rambu-rambu bagi profesi dokter, Universitas Diponegoro, 1999, hlm 157 tim dengan berbagai latar belakang keahlian, terdiri atas: operator dan ahli anestesi. Tim tersebut dapat berupa tim tunggal dengan pimpinan seorang ahli bedah yang akan bertindak sebagai captain of the ship dimana dokter anestesi termasuk didalamnya atau bisa juga berupa dua tim yang berdiri atas tim operator (terdiri ahli bedah dan asisten dan perawat) dan tim anestesi (terdiri ahli anestesi dan perawat anestesi) dengan catatan masingmasing tim punya pimpinan sendiri-sendiri yang akan bertindak sebagai captain of the ship di dalam timnya.

- Tanggung Jawab Rumah Sakit Berdasarkan Hukum \& Etika

Etik dan hukum memiliki tujuan yang sama yaitu untuk mengatur tertib dan pergaulan hidup dalam masyarakat.

Persamaan etik dan hukum adalah :

1. Sama-sama merupakan alat untuk mengatur tertibnya hidup bermasyarakat.

2. Memiliki objek yaitu tingkah laku manusia.

3. Mengandung hak dan kewajiban anggota-anggota masyarakat agar tidak saling merugikan.

4. Menggugah kesadaran untuk bersikap manusiawi.

5. Memiliki sumber yaitu hasil pemikiran para pakar dan pengalaman para anggota senior.

Perbedaan etik dan hukum adalah $:^{8}$

1. Etik berlaku untuk lingkungan profesi. Hukum berlaku untuk umum.

2. Etik disusun berdasarkan kesepakatan anggota profesi. Hukum disusun oleh badan pemerintah.

3. Etik tidak seluruhnya tertulis. Hukum tercantum secara terinci dalam kitab undang-undang dan lembaran / berita negara.

4. Sanksi terhadap pelanggaran etik berupa tuntunan. Sanksi terhadap pelanggaran hukum berupa tuntutan.

5. Pelanggaran etik diselesaikan oleh Majelis Kehormatan Etik Kedokteran (MKEK), yang dibentuk oleh Ikatan

8

https://galihendradita.wordpress.com/2018/12/24/komit e-etik-dan-hukum-rumah-sakit/. Diakses pada 23 november 2019 
Dokter Indonesia (IDI) dan apabila perlu diteruskan kepada Panitia Pembinaan Etika Kedokteran (P2EK), yang dibentuk oleh Kementerian Kesehatan (KEMKES). Pelanggaran hukum diselesaikan melalui pengadilan.

6. Penyelesaian pelanggaran etik tidak selalu disertai bukti fisik. Penyelesaian pelanggaran hukum memerlukan bukti fisik.

Sakit

1. Tanggung Jawab Hukum Rumah

Dalam Undang-Undang Nomor 44 Tahun 2009 pasal 29 ayat 1 menyatakan bahwa setiap Rumah Sakit mempunyai kewajiban sebagai berikut: $^{9}$

a. memberikan informasi yang benar tentang pelayanan Rumah Sakit kepada masyarakat;

b. memberi pelayanan kesehatan yang aman, bermutu, antidiskriminasi, dan efektif dengan mengutamakan kepentingan pasien sesuai dengan standar pelayanan Rumah Sakit;

c.memberikan pelayanan gawat darurat kepada pasien sesuai dengan kemampuan pelayanannya;

d. berperan aktif dalam memberikan pelayanan kesehatan pada bencana, sesuai dengan kemampuan pelayanannya;

e. menyediakan sarana dan pelayanan bagi masyarakat tidak mampu atau miskin;

f. melaksanakan fungsi sosial antara lain dengan memberikan fasilitas pelayanan pasien tidak mampu/miskin, pelayanan gawat darurat tanpa uang muka, ambulan gratis, pelayanan korban bencana dan kejadian luar biasa, atau bakti sosial bagi misi kemanusiaan;

g. membuat, melaksanakan, dan menjaga standar mutu pelayanan kesehatan di Rumah Sakit sebagai acuan dalam melayani pasien;

h. menyelenggarakan rekam medis;

i. menyediakan sarana dan prasarana umum yang layak antara lain sarana ibadah, parkir, ruang tunggu, sarana

\footnotetext{
${ }^{9}$ https://www.hukumonline.com Undang-Undang nomor 44 Tahun 2009 tentang Rumah Sakit, hlm 11 diakses tanggal 20 november 2019.
}

untuk orang cacat, wanita menyusui, anak-anak, lanjut usia;

j. melaksanakan sistem rujukan;

k. menolak keinginan pasien yang bertentangan dengan standar profesi dan etika serta peraturan perundangundangan;

I. memberikan informasi yang benar, jelas dan jujur mengenai hak dan kewajiban pasien;

m. menghormati dan melindungi hak-hak pasien;

n. melaksanakan etika Rumah Sakit;

o. memiliki sistem pencegahan kecelakaan dan penanggulangan bencana;

p. melaksanakan program pemerintah di bidang kesehatan baik secara regional maupun nasional;

q. membuat daftar tenaga medis yang melakukan praktik kedokteran atau kedokteran gigi dan tenaga kesehatan lainnya;

r. menyusun dan melaksanakan peraturan internal Rumah Sakit (hospital by laws);

s. melindungi dan memberikan bantuan hukum bagi semua petugas Rumah Sakit dalam melaksanakan tugas; dan t. memberlakukan seluruh lingkungan rumah sakit sebagai kawasan tanpa rokok.

Sumber lahirnya tanggung jawab hukum di Rumah Sakit : ${ }^{10}$

- Perbuatan Manajerial

- Perbuatan Medis

- Perbuatan Pelayanan Lain

\section{a). Tanggung Jawab Manajerial}

Pengoperasian Rumah Sakit :

- Menjalankan RS tanpa izin operasional

- Mempekerjakan Tenaga Kesehatan tak berizin

- Menggunakan obat tanpa izin sesuai perundang-undangan, termasuk penggunaan narkotika

- Tidak memenuhi persyaratan kesehatan, lingkungan, keselamatan bangunan, AMDAL, dll sesuai perundang-undangan

10

https://www.academia.edu/31864967/TANGGUNGJAWA B_HUKUM_DI_RUMAH_SAKIT. Dr. Mahmul Siregar SH., M.Hum, Tanggung jawab rumah sakit dalam pelayanan kesehatan. diakses tanggal 20 november 2019. 
- Tidak memenuhi standar (Akreditasi)

- Sanksi hukum

$>$ Rumah Sakit tanpa izin :

Pasal 62 UU No. 44 Tahun 2009 tentang Rumah Sakit

- Setiap orang dengan sengaja menyelenggarakan Rumah Sakit tidak memiliki izin sebagaimana dimaksud dalam pasal 25 ayat (1) dipidana dengan pidana penjara paling lama 2 (dua) tahun dan denda paling banyak Rp. 5.000.000.000,00(lima milyar rupiah).

Pasal 63 UU No. 44 Tahun 2009 tentang Rumah sakit

- (1) Dalam hal tindak pidana sebagaimana dimaksud dalam pasal 62 dilakukan oleh korporasi, selain pidana penjara dan denda terhadap pengurusnya, pidana yang dapat dijatuhkan terhadap korporasi berupa pidana denda dengan pemberatan 3 (tiga) kali dari pidana denda sebagaimana dimaksud dalam pasal 62.

- (2) Selain pidana denda sebagaimana dimaksud pada ayat (1), korporasi dapat dijatuhi pidana tambahan berupa:

* a. Pencabutan izin usaha; dan/atau

* b. Pencabutan status badan hukum.

$>$ Tenaga Kesehatan tanpa izin

Pasal 80 UU No 29 Tahun 2004 tentang Praktik Kedokteran

- $\quad$ Setiap orang yang dengan sengaja mempekerjakan dokter atau dokter gigi sebagaimana dimaksud dalam pasal 42, dipidana dengan pidana penjara paling lama 10 (sepuluh) tahun atau denda paling banyak Rp. 300.000.000,00 (tiga ratus juta rupiah).

- Dalam hal tindak pidana sebagaimana dimaksud pada ayat (1) dilakukan oleh korporasi, maka pidana yang dijatuhkan adalah pidana denda sebagaimana dimaksud pada ayat (1) ditambah sepertiga atau dijatuhi hukuman tambahan berupa pencabutan izin.

$>$ Obat tanpa izin

Pasal 197 UU No. 36 Tahun 2009 tentang Kesehatan

Setiap orang yang dengan sengaja memproduksi atau mengedarkan sediaan farmasi dan/atau alat kesehatan yang tidak memiliki izin edar sebagaimana dimaksud dalam pasal 106 ayat (1) dipidana dengan pidana penjara paling lama 15 (lima belas) tahun dan denda paling banyak Rp. 1.500.000.000,00 (satu milyar lima ratus juta rupiah).

b). Tanggung Jawab Perbuatan Medis

- Rumah Sakit Bertanggung Jawab terhadap fasilitas yang di pakai oleh tenaga medis yang sedang melakukan perbuatan medis

- Sebagai sebuah entitas hukum, RS bertanggungjawab terhadap semua kerugian yang ditimbulkan atas kelalaian yang dilakukan oleh tenaga kesehatan dirumah sakit.

- Tanggung jawab perdata atas kerugian berdasarkan pasal 1367 KUHPerdata.

$>$ Hak Menuntut Ganti Rugi

Pasal 58 UU No. 36 Tahun 2009 tentang Kesehatan

- (1) Setiap orang berhak menuntut ganti rugi terhadap seseorang, tenaga kesehatan, dan/atau penyelenggara kesehatan yang menimbulkan kerugian akibat kesalahan atau kelalaian dalam pelayanan kesehatan yang diterimanya.

(2) Tuntutan ganti rugi sebagaimana dimaksud pada ayat (1) tidak berlaku bagi tenaga kesehatan yang melakukan tindakan penyelamatan nyawa atau pencegahan kecatatan seseorang dalam keadaan darurat.

2. Tanggung Jawab Berdasarkan Etik Rumah Sakit

Etika rumah sakit adalah etika terapan (applied ethics) atau etika praktis (practical ethics), yaitu moralitas atau etika umum yang diterapkan pada isu-isu praktis, seperti perlakuan terhadap etnik-etnik minoritas, keadilan untuk kaum perempuan, penggunaan hewan untuk bahan makanan atau penelitian, pelestarian lingkungan hidup, aborsi, euthanasia, kewajiban bagi yang mampu untuk membantu yang tidak mampu dan sebagainya. Jadi, etika rumah sakit adalah etika umum yang diterapkan pada operasional rumah sakit. ${ }^{11}$

Tantangan yang dihadapi tenaga medis dan paramedis semakin besar, yang merupakan kenyataan dewasa ini dan dimasa mendatang. Hal ini berkaitan dengan pengelolaan RS dan

\footnotetext{
${ }^{11}$ https://galihendradita.wordpress.com Op.cit
} 
pelayanan kesehatan pada umumnya. Khususnya dalam pengelolaan RS, permasalahan yang selalu merupakan dilemma adalah Tarik menarik antara kepentingan kemanusiaan dengan kepentingan bisnis. Antara kepentingan sosial dan kepentingan ekonomi.

Komersialisasi pelayanan medis merupakan suatu fenomena yang masih agak baru jasa medis sudah mulai di iklankan, walaupun masih dengan hati-hati dan tidak seagresif seperti bidang lain. Saat ini telah nampak gejala yang menunjukan bahwa pelayanan kesehatan mulai bergabung dengan usaha bisnis.

Dalam kaitannya dengan penerapan audit medis di RS yaitu serangkaian kegiatan untuk menilai terhadap kegiatan medis tertentu, sangat diharapkan sebagai upaya untuk mengantisipasi perkembangan dan perubahan struktur sosial ekonomi dan kultural yang cepat, sehingga menimbulkan suatu keadaan "transisi" yang mengakibatkan perangkat hukum dan etik profesi tidak dapat menjangkau apa yang dilakukan oleh tenaga kesehatan, yang pada dasarnya telah menimbulkan kerugian bagi masyarakat. Masalah etik dan hukum di RS dihadapi oleh semua pihak yang ada di RS. Wadah audit medis dibentuk untuk menghadapi masalah-masalah yang ditimbulkan oleh ketentuan-ketentuan etik yang berimplikasi terhadap pelanggaran hukum yang pelik dan kompleks yang dirasakan oleh pasien, keluarganya dan tenaga kesehatan lainnya di RS. Wadah ini seringkali berperan dalam membantu para dokter, perawat dan anggota tim kesehatan lainnya di RS dalam menghadapi dilema etik.

Munculnya masalah dalam pengelolaan RS sering meningkatkan jumlah pelanggaran etik yang disebabkan karena tidak jelasnya hubungan kerja antara dokter dengan RS. Tidak adanya suatu kontrak/perjanjian kerja yang jelas yang mengatur hak dan kewajiban masingmasing pihak. Sementara itu dibidang teknologi, pelanggaran etik juga dimungkinkan karena pemilihan teknologi yang tidak didahului dengan baik pengkajian teknologi maupun pengkajian ekonomi dan menyebabkan kemungkinan tindakan yang tidak etis kepada pasien yang berupa pembebanan biaya. ${ }^{12}$

\footnotetext{
${ }^{12}$ Theodorus Lumenon, Modul E-Learning Hukum Kesehatan, Manado hlm 72.
}

\section{B. Tanggung Jawab Dokter Dalam Transaksi Terapeutik}

Tanggungjawab seorang dokter, Poerwadarminta dalam kamus Umum Bahasa Indonesia memberikan definisi bahwa "tanggungjawab (hukum) seorang dokter adalah keadaan yang mewajibkan dokter untuk menanggung segala sesuatunya, kalau ada terjadi sesuatu hal maka boleh dituntut atau dipersalahkan atau diperkarakan dan sebagainya. ${ }^{13}$

Mekanisme pertanggungjawaban hukum dokter merupakan proses pembuktian dari suatu kelalaian atau pun kesalahan yang di lakukan dokter dalam profesi kedokterannya dengan menyatakan perbuatannya benar murni sebuah kesalahan. Dalam hal ini bukti yang harus ditemukan merupakan sebab terjadinya perbuatan pidana tersebut dan apakah terdapat akibat yang terjadi/timbul disebabkan oleh tindakan dokter yang sengaja bersikap kurang hati-hati dan ceroboh. Dalam pembuktian di Hukum Perdata seseorang dapat mengajukan gugatan melakukan perbuatan melanggar hukum haruslah dipenuhi empat syarat yang disebutkan dalam pasal 1365 KUHPerdata: ${ }^{14}$

1. Pasien harus mengalami kerugian.

2. Ada kesalahan atau kelalaian (disamping perorangan, rumah sakit juga bisa bertanggungjawab atas kesalahan atau kelalaian pegawainya).

3. Ada hubungan kausal antara kerugian dan kesalahan.

4. Perbuatan itu melanggar hukum.

Dokter harus benar-benar mengetahui apa yang menjadi kewajibannya dan apa yang menjadi haknya. Berkaitan dengan kewajiban hukum maka hal tersebut menyangkut apa yang boleh dan tidak boleh dilakukan, atau apa yang seharusnya dilakukan maupun tidak seharusnya dilakukan oleh dokter dalam melaksanakan profesinya. Dalam menjalankan profesinya lebih khusus dalam melaksanakan tanggung jawabnya, seorang dokter terikat pada ketentuan-ketentuan hukum, dan harus

\footnotetext{
13 Poerwadarminta, WJS, 1976, Kamus Umum Bahasa Indonesia, Jakarta, Balai Pustaka, Cet.ke-1.

14 Soetrisno, Malpraktek Medik \& Mediasi Sebagai Alternatif Penyelesaian Sengketa, Telaga IImu, Tangerang, 2010, hlm.
} 
memenuhi tanggung jawab hukum. Tanggung jawab hukum dalam hukum perdata merupakan tanggung jawab seseorang terhadap perbuatan yang melawan hukum. Perbuatan melawan hukum tidak hanya mencakup perbuatan yang bertentangan dengan undang-undang pidana saja, akan tetapi jika perbuatan tersebut bertentangan dengan undang-undang lainnya dan bahkan bertentangan dengan ketentuan-ketentuan hukum yang tidak tertulis. ${ }^{15}$ Pertanggungjawaban hukum perdata bertujuan untuk memperoleh ganti rugi atas segala yang diderita oleh si penderita atau pasien.

Bentuk pertanggungjawaban hukum perdata adalah antara lain seperti yang diatur dalam:

1. Undang-Undang Hukum Perdata
(KUHPerdata), antara lain:

a. Pasal 1239 Kitab Undang-Undang Hukum Perdata Tanggung gugat berdasarkan wanprestasi atau cedera janji atau ingkar janji.

b. Pasal 1365 Kitab Undang-Undang Hukum Perdata Tanggung gugat berdasarkan perbuatan melawan hukum, "tiap-tiap perbuatan melanggar hukum, yang membawa kerugian kepada seorang lain, mewajibkan orang yang karena salahnya menerbitkan kerugian itu, mengganti kerugian tersebut.

c. Pasal 1366 Kitab Undang-Undang Hukum Perdata, melakukan kelalaian sehingga menyebabkan kerugian, "setiap orang bertanggungjawab tidak saja untuk kerugian yang disebabkan perbuatannya, tetapi juga untuk kerugian yang disebabkan kelalaian atau kurang hatihatinya".

d. Pasal 1367 Kitab Undang-Undang Hukum Perdata, melalaikan pekerjaan sebagai penanggungjawab, "seseorang tidak saja bertanggung jawab untuk kerugian yang disebabkan karena perbuatannya sendiri, tetapi juga untuk kerugian yang disebabkan karena perbuatan orangorang yang menjadi tanggungannya atau disebabkan oleh barang-barang yang berada dibawah pengawasannya".

e. pasal 1243 undang-undang KUHPerdata Wanprestasi, dalam hal ini dokter tidak

15 Komariah, Edisi Revisi Hukum Perdata, Malang: Universitas Muhammadiyah Malang, 2001, hlm 12 memenuhi kewajibannya yang timbul dari suatu perjanjian (tanggung jawab kontraktual), yang diawali dengan adanya perjanjian yang melahirkan hak dan kewajiban. Apabila dalam hubungan hukum berdasarkan perjanjian tersebut, pihak yang melanggar kewajiban (debitur) tidak melaksanakan atau melanggar kewajiban yang dibebankan kepadanya maka ia dapat dinyatakan lalai (wanprestasi) dan atas dasar itu ia dapat dimintakan pertanggungjawaban hukum berdasarkan wanprestasi.

- Hubungan Hukum Dokter-Pasien Dalam Kontrak Terapeutik Membentuk PertanggungJawaban Perdata

Dari sudut Hukum Perdata, hubungan hukum dokter-pasien berada dalam suatu perikatan hukum (verbintenis). Istilah perikatan ini lebih umum dipakai dalam literatur hukum indonesia. Perikatan artinya hal yang mengikat subjek hukum yang satu terhadap subjek hukum yang lain. ${ }^{16}$

Dalam hubungan hukum dokter-pasien disamping melahirkan hak dan kewajiban para pihak, juga membentuk pertanggungjawaban hukum masing-masing. Bagi pihak dokter, prestasi berbuat sesuatu atau tidak berbuat sesuatu in casu tidak berbuat salah atau keliru dalam perlakuan medis yang semata-mata ditunjukan bagi kepentingan kesehatan pasien, adalah kewajiban hukum yang sangat mendasar dalam perjanjian dokter-pasien (kontrak terapeutik), yang dalam Undang-Undang Nomor 29 Tahun 2004 tentang Praktek Kedokteran disebut dengan kalimat singkat ialah "kesepakatan antara dokter atau dokter gigi dengan pasien" (Pasal 39). ${ }^{17}$

Ukuran perlakuan berbuat sesuatu secara maksimal dan dengan sebaik-baiknya atau tidak berbuat sesuatu yang tidak perlu, didasarkan pada standar profesi medis dan standar prosedur. Dalam Undang-Undang Nomor 29 Tahun 2004 tentang Praktik Kedokteran, ukuran itu disebutkan dengan istilah "Standar Profesi

\footnotetext{
${ }^{16}$ Abdulkadir Muhamad, Hukum Perikatan, Alumni, 1982, hlm 5

${ }^{17}$ Adami Chazawi, Malapraktik Kedokteran, Sinar Grafika, 2015, hlm 35
} 
dan Standar Prosedur Operasional" (Pasal 50 juncto pasal 51).

Dari sudut perdata, malapraktik kedokteran terjadi apabila perlakuan salah dokter dalam hubungannya dengan pemberian prestasi pelayanan medis pada pasien menimbulkan kerugian keperdataan. Hal ini terkadang berbarengan dengan akibat yang menjadi unsur tindak pidana tertentu. Unsur adanya kerugian kesehatan fisik, jiwa maupun nyawa pasien akibat dari salah perlakuan oleh dokter, merupakan unsur esensial malapraktik kedokteran perdata maupun pidana. Dengan timbulnya akibat kerugian perdata bagi pasien sebagai dasar terbentuknya pertanggungjawaban hukum perdata bagi dokter.

Dilihat dari sumber lahirnya perikatan, ada dua kelompok perikatan hukum. Kelompok yang satu ialah perikatan-perikatan yang lahir dari suatu kesepakatan (Pasal 1313-1351 BW), dan yang lainnya oleh sebab UU (Pasal 13521380 BW). Hubungan hukum dokter-pasien berada dalam keduan jenis perikatan hukum tersebut. Pelanggaran kewajiban hukum dokter dalam perikatan hukum karena kesepakatan (kontrak terapeutik) membawa suatu keadaan wanprestasi. Pelanggaran hukum dokter terhadap kewajiban dokter karena UU membawa suatu keadaan perbuatan melawan hukum (onrechtmatige daad, Pasal 1365 BW). ${ }^{18}$

Pelanggaran suatu kewajiban hukum karena UU bisa terjadi apa yang disebut zaakwaarneming (Pasal 1354 BW). Zaakwaarneming berupa melakukan sesuatu dengan diam-diam dan secara sukarela untuk kepentingan orang lain tanpa persetujuannya dan tanpa sepengetahuannya menimbulkan suatu kewajiban pelaksanaan dengan sebaikbaiknya, dan oleh karenanya melahirkan tanggung jawab terhadap akibat yang timbul apabila ada kesalahan dalam pelaksanaan sesuatu tersebut. Keadaan wanprestasi, onrechtmatige daad mapun pelanggaran kewajiban dalam zaakwaarneming dalam hubungan hukum dokter-pasien membentuk pertanggungjawaban hukum bagi dokter terhadap kerugian yang timbul. ${ }^{19}$

\section{- Contoh Kasus}

\footnotetext{
${ }^{18} \mathrm{Ibid}, \mathrm{hlm} 36$

${ }^{19} \mathrm{lbid}, \mathrm{h} / \mathrm{m} 37$
}

Dokter Dewa Ayu Sasiarsy atau biasa dipanggil dr Ayu yang divonis penjara oleh Mahkamah Agung (MA) karena gagal menyelamatkan nasib pasiennya. dr Ayu yang bersama rekannya yaitu dr Hendry Simanjuntak dan dr Hendy Siagian sedang menangani pasien rujukan puskesmas di daerah manado. Karena keadaan terdesak, dr Ayu melakukan tindakan operasi cito secsio sesaria. Tetapi tindakan itu gagal menyelamatkan pasien. dr Ayu pun dituntut oleh pihak keluarga pasien karena melakukan operasi tanpa izin. Pada persidangan di Pengadilan Negeri Manado, dr Ayu dituntut 10 bulan penjara. Tapi dr Ayu divonis bebas karena tidak terbukti melakukan malpraktik. Jaksa penuntut umum yang menangani kasus tersebut mengajukan kasasi yang dikabulkan oleh Mahkamah Agung (MA) lewat putusan yang dikeluarkan pada 18 November 2012 lalu. Kasasi ini memerintahkan dokter Ayu dan rekan-rekan untuk dipenjara selama 10 bulan. Pada februari 2014 dr Ayu di bebaskan lewat putusan di tingkat peninjauan kembali (PK). Dasar pertimbangan mengabulkan PK yaitu terpidana tidak menyalahi SOP dalam penanganan operasi sesco ciceasria sehingga pertimbangan judex facti pada Pengadilan Negeri manado sudah tepat dan benar. ${ }^{20}$

\section{PENUTUP}

\section{A. Kesimpulan}

Hubungan antara rumah sakit-dokter-pasien adalah berdasarkan hubungan terapeutik yang dimana melahirkan hak dan kewajiban dari para pihak. Pada pasal 46 Undang-Undang Nomor 44 Tahun 2009 tentang Rumah Sakit dapat ditafsirkan bahwa rumah sakit dapat bertanggungjawab terhadap kelalaian tenaga kesehatan, Rumah Sakit dapat bertanggung jawab terhadap kerugian akibat dari kelalaian, Rumah Sakit tidak bertanggung jawab jika terbukti tidak adanya kelalaian yang dilakukan

20 https://m.liputan6.com/news/read/757089/kasusdokter-ayu-cs-ky-mungkin-saja-lalai. diakses tanggal 1 februari 2020 
tenaga kesehatan, Rumah Sakit tidak bertanggung jawab terhadap tindakan kesengajaan tenaga kesehatan yang menimbulkan kerugian seseorang, Rumah Sakit tidak bertanggung jawab terhadap kelalaian akibat tindakan medis yang dilakukan tenaga medis yang bukan pegawainya, Tenaga Medis dapat bertanggung jawab terhadap kerugian yang ditimbulkan akibat dari kelalaian yang dilakukannya.

\section{B. Saran}

Di Indonesia malpraktek belum diatur dalam Undang-Undang manapun untuk itulah masyarakat memahami bahwa semua tindakan kelalaian dokter adalah murni perbuatan malpraktik, dikarenakan tidak adanya definisi baku tentang malpraktik sendiri. Pemerintah harus membuat adanya Undang-Undang yang mengatur khusus tentang malpraktik medis dan membuat definisi baku mengenai malpraktik agar masyarakat dapat membedakan apa itu kelalaian dan kesengajaan. Dokter melakukan informed consent (persetujuan tindakan medis) haruslah dengan baik dan jelas. Menggunakan tata bahasa yang baik dan mudah dimengerti pasien sehingga pasien mengerti manfaat dari tindakan dokter kepada pasien.

\section{DAFTAR PUSTAKA}

Sri Siswati, Etika dan Hukum Kesehatan depok: Rajawali Pers, 2017

https://ejournal.undip.ac.id/index.php/mmh/ar ticle/view/9920/8340,diakses tanggal 5 oktober 2019

https://id.m.wikipedia.org/wiki/Rumah_sakit_p ublik, diakses tanggal 5 oktober 2019

S.Wahyud - Jurnal Dinamika Hukum, 2011 dinamikahukum.fh.unsoed.ac.id, diakses tanggal 5 oktober 2019

Repository.usu.ac.id - Tinjauan umum tentang tanggung jawab rumah sakit sebagai pelaku usaha., diakses tanggal 5 oktober 2019

Fh.unsoed.ac.id - Tanggung jawab rumah sakit terhadap kerugian akibat kelalaian tenaga kesehatan dan implikasinya.,diakes tanggal 5 oktober 2019

www.mkekpbidi.org - Kodeki I MKEK PB IDI diakses tanggal 14 oktober 2019
C.S.T. Kansil. Pengantar Hukum Kesehatan Indonesia,( Rineka Cipta, Jakarta, 1991)

https://ngada.org/bn259-2011.htm, diakses tanggal 14 oktober 2019

juke.kedokteran.unila.ac.id diakses tanggal 14 oktober 2019

https://excellentlawyer.blogspot.com/2010/04/badanhukum-rumah-sakit.html. Diakses tanggal 20 november 2019

Hamidi Jazim, Hukum Lembaga Kepresidenan Indonesia, Alumni, Malang.

Ranawijaya Usep, Hukum Tata Negara Dasardasarnya, Gahlia Indonesia, Jakarta, 1983,

Kusnardi, Pengantar Hukum Tata Negara Indonesia, PS HTN FH UI dan Sinar Bakti, Jakarta, 1983,

Utrecht, Pengantar Hukum Administrasi Negara Indonesia, Sinar Harapan, Jakarta, 1989,

Cipto B. Hestu, Hukum Tata Negara Indonesia, Universitas Atmajaya, Yogyakarta, 2009,

Endang Wahyati Yustina, Mengenal Hukum Rumah Sakit, Keni Media, Bandung, 2012,

Aditama Tjandra Yoga, Manajemen Rumah Sakit, Universitas Indonesia, Jakara, 2007,

Kusuma Endang, Transaksi Terapeutik Dalam Pelayanan Medis di Rumah Sakit, Citra Aditya Bakti, Bandung, 2009,

Iskandar Dalmy, Hukum Rumah Sakit dan Tenaga Kesehatan, Sinar Grafika, Jakarta, 1998,

P.N.H Simanjuntak, Pokok-Pokok Hukum Perdata Indonesia, Jakarta:Djambatan, 2009,

Komarlah, Hukum Perdata, Malang: UMM Press, 2002,

Setyono, Kejahatan Korporasi, Malang: Bayumedia Publshingi, 2003.I

Theodorus Lumenon, Modul E-Learning Hukum Kesehatan, Manado

Arus Akbar Silonde, Wirawan B. Ilyas, PokokPokok Hukum Bisnis, Salemba Empat, Jakarta, 2013,

Mulhadi, Hukum Perusahaan : Bentuk-bentuk Badan Usaha di Indonesia, Ghalia Indonesia, Bogor, 2010,

M.A. Moegni Djojodirdjo, Perbuatan Melawan Hukum, cet.2, Jakarta : Pradnya Paramita, 1982, 
Munir Faudi, Perbuatan Melawan Hukum, Bandung : PT. Citra Aditya Bakti, 2002,

R. Wirjono Projodikoro, Perbuatan Melanggar Hukum, Bandung :Sumur1994,

Ridwan Halim. Pengantar Hukum dan Pengetahuan IImu Hukum Indonesia. Jakarta: Angky Pelita Studyways, 2001.

Undang-Undang No. 29 Tahun 2004 tentang Praktik kedokteran.

Anny Isfandyarie, Tanggung Jawab Hukum dan Sanksi bagi Dokter Buku I, Prestasi Pustaka: Jakarta, 2006,

http://alisarjuni.blogspot.com/2013/05/hukum -tanggung-jawab-dokter-dengan.html, diakses tanggal 2 november 2019

Juanda, Hukum Pemerintah Daerah: Pasang surut hubungan antara DPRD dan Kepala Daerah, Bandung 2004, Alumni Hal 105106 dikutip dari Bahruddin Salam, Etika Moral : Asas Moral dalam kehidupan sosial Manusia, Renika Cipta Jakarta 1997, hIm 28 dikutip dari Isa Wahyudi, Busyra Azheri, Corporate Social Responsibility : Prinsip, Pengaturan dan Implementasi,Setara press dan INSPIRE, Malang, $2011 \mathrm{hlm} 4$

Sentosa, Mas Achmad, Good Governence dan Hukum lingkungan, ICEI,Jakarta, 2001

https://galihendradita.wordpress.com/2018/12 /24/komite-etik-dan-hukum-rumahsakit/. Diakses pada 23 november 2019

https://www.hukumonline.com UndangUndang nomor 44 Tahun 2009 tentang Rumah Sakit, diakses tanggal 20 november 2019.

https://www.academia.edu/31864967/TANGG UNGJAWAB_HUKUM_DI_RUMAH_SAKIT. Dr. Mahmul Siregar SH., M.Hum, Tanggung jawab rumah sakit dalam pelayanan kesehatan. diakses tanggal 20 november 2019.

Siti Ismijati Jenie. 1994. Beberapa Aspek Yuridis di Dalam dan di Sekitar Perjanjian Penyembuhan. UGM, Yogyakarta.

Guwandi, J. 2006. Dugaan Malpraktek Medik dan Draft RPP Perjanjian Terapeutik Antara Dokter dan Pasien. Fakultas Kedokteran Universitas Indonesia, Jakarta.

Hermien Hadiati Koeswaji. 2002. Hukum Kedokteran Studi Tentang Hubungan
Hukum Dalam Mana Dokter Sebagai Salah Satu Pihak. Penerbit PT Citra Aditya Bakti, Bandung.

Abdulkadir Muhamad, Hukum Perikatan, Alumni, 1982,

Adami Chazawi, Malapraktik Kedokteran, Sinar Grafika, 2015, 